\title{
Ergosterol Isolated from Agaricus blazei Murill N-Hexane Extracts as Potential Anticancer MCF-7 Activity
}

\author{
Misgiati Misgiati ${ }^{1,2}$, Aty Widyawaruyanti ${ }^{3}$, Sentot Joko Raharjo ${ }^{2}$, Sukardiman Sukardiman ${ }^{4, *}$
}

Misgiati Misgiati ${ }^{1,2}$, Aty

Widyawaruyanti ${ }^{3}$, Sentot

Joko Raharjo ${ }^{2}$, Sukardiman

Sukardiman ${ }^{4, *}$

'Post Graduate Student of Department of Pharmacognosy and Phytochemistry, Faculty of Pharmacy, Airlangga University, Surabaya 6011, INDONESIA.

${ }^{2}$ Academic of Pharmacy and Food Analyst of Putra Indonesia Malang, Jl. Barito 5 Malang 65123, INDONESIA

${ }^{3}$ Natural Product Medicine Research and Development, Institute of Tropical Disease, Airlangga University, Surabaya 6011, INDONESIA.

${ }^{4}$ Department of Pharmacognosy and Phytochemistry, Faculty of Pharmacy, Airlangga University, Surabaya 6011, INDONESIA.

\section{Correspondence}

\section{Sukardiman}

Department of Pharmocognosy and Phytochemistry Faculty of Pharmacy Universitas Airlangga Surabaya, INDONESIA

E-mail: sukardiman@ff.unair.ac.id

History

- Submission Date: 15-12-2020;

- Review completed: 28-01-2021;

- Accepted Date: 02-02-2021.

DOI : 10.5530/pj.2021.13.53

Article Available online

http://www.phcogj.com/v13/i2

Copyright

(C) 2021 Phcogj.Com. This is an openaccess article distributed under the terms of the Creative Commons Attribution 4.0 International license.

\section{ABSTRACT}

Extracts and some of the Agaricus blazrei Murill isolates have potential anticancer. Ergosterol isolate from Amaouroderma rude can also inhibit the growth of MDA-MB-231 cancer cells through apoptotic pathways by increasing FOXO3 expression, while its potency against MCF-7 cells has not been reported. The purpose of this study was to isolate, determine the structure, determine the anticancer activity of MCF-7 cells, and the isolate mechanism by apoptosis from one of isolates the n-hexane A.blazei Murill extracts. This research method includes the isolation of compounds from A.blazei Murill extract by chromatography method guided using Bioactivity Guided Isolation. The structure elucidation of structure isolates used UV, NMR and MS spectroscopy. Anticancer activity test using the MTT cytotoxic test. Eludation of UV, NMR and MS structures showed a ergostrerol. The anticancer activity test showed $I C_{50}$ values of $43.10 \mu \mathrm{g} / \mathrm{mL}$ with the strong cytotoxic category. The mechanism of action is to increase apoptosis induction through inhibition of the cell cycle in the G2/ M phase. The conclusion of the isolated compound was ergosterol with an $\mathrm{IC}_{50}$ value of $43.10 \mu \mathrm{g} / \mathrm{mL}$ with an increased apoptosis induction mechanism through inhibition of the cell cycle in the $\mathrm{G} 2 / \mathrm{M}$ phase.

Key words: Agaricus blazei, Murill extract, Egosterol, MCF-7 cells, Apoptosis.

\section{INTRODUCTION}

Agaricus blazeii Murill is a low-level plant which is a functional food and has the potential to have activities both in vitro and in vivo, including reducing blood sugar, lowering blood pressure, reducing cholesterol, reducing arteriosclerosis ${ }^{1-11}$, antioxidant, antiviral, antimutagenic, anticarcinogenic., ${ }^{72-19}$ Other names for Agaricus blazei Murill are A.subrufescens, A.sylvaticus, and A.brasiliensis ${ }^{13}$. Several studies have been carrying out related to the activity of the extract as an anticancer, namely research on $50 \%$ ethanol extract of Agaricus blazei Murill that can inhibit the growth of Hela cells with an IC50 value of $194.4 \mu \mathrm{g} /$ mL. ${ }^{17}$ Agaricus blazei Muril extract can also inhibit myolema cells and leukemia cells ${ }^{20-24}$. Agaritin isolates from Agaricus blazei Murill can also inhibit the proliferation of leukemia cancer cells U937, MOLT4, HL-60, and K-562 with $\mathrm{IC}_{50}$ values of 2.7; 9.4; 13.0; and $16.0 \mu \mathrm{g} / \mathrm{mL}^{1}$. Blazein isolate from Agaricus blazei Murill extract can also induce the death of human lung LU99 and stomach KATO III cancer line at a concentration of $200 \mu \mathrm{g} / \mathrm{mL} \cdot .^{25,26}$ Polysaccharides obtained from the isolation process of Agaricus blazei Murill extract have the potential to inhibit osteosarcoma cell proliferation (HOS cell line) at a concentration of $100 \mu \mathrm{g} / \mathrm{mL}$. Agaricus blazei Murill extract can inhibit proliferation in DU145 and PC3 prostate cancer cells $400 \mu \mathrm{g} / \mathrm{mL}$ and $800 \mu \mathrm{g} / \mathrm{mL} .^{27}$ Hot water extract of Agaricus blazei Murill also inhibits the growth of pancreatic cells. $^{16}$

Several previous studies have also shown that the isolated compounds associated with the divine mushroom isolate have anti-cancer mechanisms, such as $\beta$-D-glucan and ergosterol isolate. $\beta$-Dglucan can cause apoptosis in human ovarian cells which will involve the p38 MAPK (Mitogen Activated Protein Kinase) pathway by translocation of apoptotic activator from the cytosol to mitochondria, cytochrome $\mathrm{c}$ is formed which then activates caspase 9. ${ }^{14,22}$ stated that $\beta$-D-glucan isolate from the fungus Botryosphaeria rhodina can also increase apoptosis, oxidative stress, mRNA expression for p53, p27, and Bax (Bcl-2 Associated X -protein), activated AMPprotein kinase (Adenosine monophosphate protein kinase), transcription factor FOXO3a (Forkhead Box O3), Caspase3, and decreased p70S6K (Ribosomal protein S6 kinase beta-1) in MCF-7 cells. Ergosterol isolated from Amaouroderma rude can suppress the growth of breast cancer cells through the apoptotic pathway by increasing the expression of FOXO3. ${ }^{15}$

Previous studies showed that the activity test of n-hexane, dichloromethane, chloroform, ethyl acetate, and butanol extracts against MCF-7 cancer cells obtained $\mathrm{IC}_{50}$ results of $24.72 \mu \mathrm{g} / \mathrm{mL} ; 22.70 \mu \mathrm{g} /$ $\mathrm{mL} ; 21.56 \mu \mathrm{g} / \mathrm{mL} ; 23.49 \mu \mathrm{g} / \mathrm{mL}$; and $50.08 \mu \mathrm{g} / \mathrm{mL}$ which is included in the strong cytotoxicity category, while the water extract is inactive. ${ }^{18}$. Statistical analysis t-test on the results of the $\mathrm{IC}_{50}$ value on the treatment of $\mathrm{n}$-hexane extract, dichloromethane extract, chloroform extract, and ethyl acetate extract obtained a sig value of $0.356(>0.05)$, so that the treatment of the extract for the $\mathrm{IC}_{50}$ value showed no difference. Based on these data, several compounds were isolated from the n-hexane extract first. The isolation process was carrying out by the chromatography method guided by the Bioactivity Guided Isolation method and the determination of 
the eludation of the structure resulting from the isolation. The activity of the isolates was carrying out on MCF-7 cancer cells. The purpose of this study was to elucidate the structure of isolates with UV spectrum, NMR spectrum, and MS results from the isolation of Agaricus blazei Murill $n$-hexane extract and determine the anticancer activity of MCF7 cells and their mechanisms.

\section{MATERIAL AND METHODS}

\section{General}

The HPLC system consists of two LC-10AD pumps and an SCL10A controller, Agilent RP-18 XDB 4.6x250mm column, eluted with methanol: acid water (9.95: 0.05 ) at $2 \mathrm{~mL} / \mathrm{min}$ flow rate, UV-Vis Spectrum analyzed using UV-1900i UV-Vis Spectrophotometer, NMR spectrum recorded on JEOL ECS-400, using $\mathrm{CDCl}_{3}$ as solvent. Vacuum Column Chromatography (VLC) with silica Gel $\mathrm{F}_{254}$ (Merck, No 1.07730.0500) and Thin Layer Chromatography (TLC) on Silica Gel 60 $\mathrm{F}_{254}$ (Merck, 1.05715.0001) and Silica RP -18 (Merck, No 1.15389.0001). TLC profile identification was carry out using the TLC Visualizer (Camag)

\section{Plant material}

Agaricus blazei Murill obtained from traditional medicine industry PT. ASIMAS Lawang Malang.

\section{Isolation and identification of active compounds}

Blend dry Agaricus blazei Murill. The resulting powder extracted by maceration. The hexane extract was fraction using Vacuum Column Chromatography (VLC) with a gradient of n-hexane and ethyl acetate $(100 \%-0 \%)$. Based on the thin layer chromatography profile, several fractions of the same were combine to produce three fractions. Each fraction was identified with TLC Silica Gel $60 \mathrm{~F}_{254}$ (Merck, 1.05715.0001) and Silica RP-18 (Merck, No 1.15389.0001) and tested for the anticancer activity of MCF-7 cells. Activity testing the fraction that has the smallest activity is separate by dissolving it with methanol to produce two sub-fractions. Sub-fraction was carry out by the anticancer activity of MCF-7 cells. The sub-fraction which have the smallest activity is carried out semi preparative separation by the HPLC (High Liquid Pressure Chromatography) method consisting of two LC$10 \mathrm{AD}$ pumps and an SCL-10A controller, Agilent RP-18 XDB column 4.6x250mm, elongated with methanol: acid water (9, 95: 0.05). Subfraction were exfoliat in a formic acidic and methanol mixture (9.95: $0.05 \mathrm{v} / \mathrm{v}$ ) with a flow rate of $1 \mathrm{ml} /$ minute, obtained 5 isolates. The isolate profiles were analyst using TLC and HPLC.

Isolates were analyst using TLC, visualized at UV $254 \mathrm{~nm}$ and $366 \mathrm{~nm}$, and sprayed with anisaldehyde to see the presence of terpenoids. The isolates were test for the anticancer activity of MCF-7 cells. Isolates that are sufficient in number and have anticancer activity for MCF-7 cells are determined for their chemical structure. The chemical structure was determined using Nuclear Magnetic Resonance (JEOL, ECS-400) with $\mathrm{CDCl}_{3}$ as the solvent. The mass spectrum was identification by the LCMSMS system with Coloum: ACQUITY UPLC @ BEH C18 $1.7 \mu \mathrm{m}$.

\section{MTT cytotoxic test ${ }^{8}$}

According to the Cancer Chemoprevention Research Center (2013), the cytotoxic test of the MTT method was carry out by implanting MCF-7 cells planted in 5000 cells/ wells 96 microplate and incubated for 48 hours to get good growth. The MEM medium was replace with new samples added at various concentrations $(3.375 \mu \mathrm{g} / \mathrm{mL}, 6.75 \mu \mathrm{g} / \mathrm{mL}$, $12.5 \mu \mathrm{g} / \mathrm{mL}, 25 \mu \mathrm{g} / \mathrm{mL}, 50 \mu \mathrm{g} / \mathrm{mL}$, cell control, solvent control) with DMSO co-solvent and incubated at $37^{\circ} \mathrm{C}$ in a $5 \% \mathrm{CO}_{2}$ incubator for 48 hours. At the end of incubation, MEM media and extract were discard and the cells were wash with PBS. To each well, $10 \mu \mathrm{l}$ of MTT reaction 5 $\mathrm{mg} / \mathrm{mL}$ was add cell were incubated for $4-6$ hours in a $5 \% \mathrm{CO}_{2}$ incubator at $37^{\circ} \mathrm{C}$. The MTT reaction was stopped with isopropanol acid reagent ( $\mathrm{HCl} 4 \mathrm{~N}$ and isopropanol; 1: 4), shaken on a shaker for 10 minutes. The absorption was reading with an ELISA reader at a wavelength of $550 \mathrm{~nm}$. Data collection for the cytotoxic test is a) The absorbance data obtained from the cytotoxic test is converted into percent of living cells, b) The percentage of living cells is calculated using the formula:

Absorbance of cells with treatment - Absorbance of cell media control

$$
\% \text { Living Cells }=\frac{\text { Absorbance of cells with treatment }- \text { Absorbance of cell media control }}{\text { Absorbance of cell media control - Absorbance of control media }} \times 100 \%
$$

Absorbance of cell media control - Absorbance of control media

Anticancer activity criteria, that $\mathrm{IC}_{50}<10 \mu \mathrm{g} / \mathrm{ml}$ (very strong cytotoxicity), $\mathrm{IC}_{50}=10-100 \mu \mathrm{g} / \mathrm{mL}$ (strong cytotoxicity), and $\mathrm{IC}_{50}=100-$ $500 \mu \mathrm{g} / \mathrm{mL}$ (moderate cytotoxicity) ${ }^{25}$

\section{Testing of isolates against apoptosis induction by} flowcytometry ${ }^{8}$

Cells as many as $5 \times 10^{5}$ cells / well were planting in 6-well plates then the cells were incubating until normal. Cells were treating with DMSO solvent $(0.25 \%)$ and active isolate at $\mathrm{IC}_{50}$. The cells were then incubating again for 24 hours. At the end of the incubation time, the media taken and transferred into a centrifuge tube and centrifuged $(2000 \mathrm{rpm}, 3$ minutes) then the supernatant was discarding. In wells that have been taken, the media, added with PBS, and PBS are transferred to the same micro tube from one treatment, and then centrifuged and then the supernatant is discarded. This stage is repeating once more then the cells are harvesting with trypsin. Cells were transferring into the same micro tube and then centrifuged (2000 rpm, 3 minutes). The remaining harvested cells in the well are rinsed with PBS and centrifuged again, then PBS is discarded. The precipitate was adding with the PIAnnexin $\mathrm{V}$ reagent carefully and immediately homogenized. Micro tubes containing cell suspension were wrapping in aluminum foil and incubated in a $37^{\circ} \mathrm{C}$ water bath for 5 minutes. The cell suspension homogenized again and transferred into a flow6cytometer tube, using a nylon filter, and then it was ready to be analysis using a flow cytometer.

\section{RESULT}

\section{Isolation and identification of active substances}

4 gram n-hexane extract was fractionated with VLC using a gradient mobile phase of $n$-hexane and ethyl acetate $(100 \%-0 \%)$ to produce three fractions (Fractions 1-3, $45 \mathrm{mg} ; 247,6 \mathrm{mg}$; and 632,4 mg). Identification using TLC showed that the third fraction contained a bluish purple color indicating the presence of terpenoids. The third fraction is separate by dissolving with methanol, to separate the residue and filtrate. The residue was separate by semi preparative HPLC with methanol: acid water (9.95: 0.05) to produce five isolates (isolates 1-5, 0 $\mathrm{mg} ; 4 \mathrm{mg} ; 1 \mathrm{mg}$; $0 \mathrm{mg}$; and 0,7mg).

In vitro testing of isolates on MCF-7 cells with an $\mathrm{IC}_{50}$ value of $43.51 \mu \mathrm{g} /$ $\mathrm{mL}$. This isolate was analyze by HPLC (Figure $1[\mathrm{~A}]$ ) at a concentration of $0.5 \mathrm{mg} / \mathrm{mL}$, using methanol: acid $(9.95: 0.05 \mathrm{v} / \mathrm{v})$ as a solvent, indicating a major peek with a retention time of 24.39 minutes. The results of the UV spectrum of these compounds showed the absorption at $\lambda_{\max } 262,271,282$, and $293 \mathrm{~nm}$ (Figure 1 [B]), which had the same absorption values as the ergosterol standards, namely $262,271,282$, and $293 \mathrm{~nm}^{21}$. Based on the ${ }^{1} \mathrm{HNMR}$ spectrum, (i) there is an overlapping aliphatic proton signal in the $0.50-2.50 \mathrm{bpj}$ region which indicates the characteristic of terpenoids, (ii) there are six methyl signals at $\delta 0.93$ (3H, s, H-18) shift; 0.62 (3H, s, H-19); $1.03(3 \mathrm{H}, \mathrm{d}, \mathrm{J}=6.5 \mathrm{~Hz}, \mathrm{H}-21)$; $0.92(3 \mathrm{H}, \mathrm{d}, \mathrm{J}=6.5 \mathrm{~Hz}, \mathrm{H}-28) ; 0.84(3 \mathrm{H}, \mathrm{d}, \mathrm{J}=6.6 \mathrm{~Hz}, \mathrm{H}-26) ; 0.82(3 \mathrm{H}, \mathrm{d}$, 


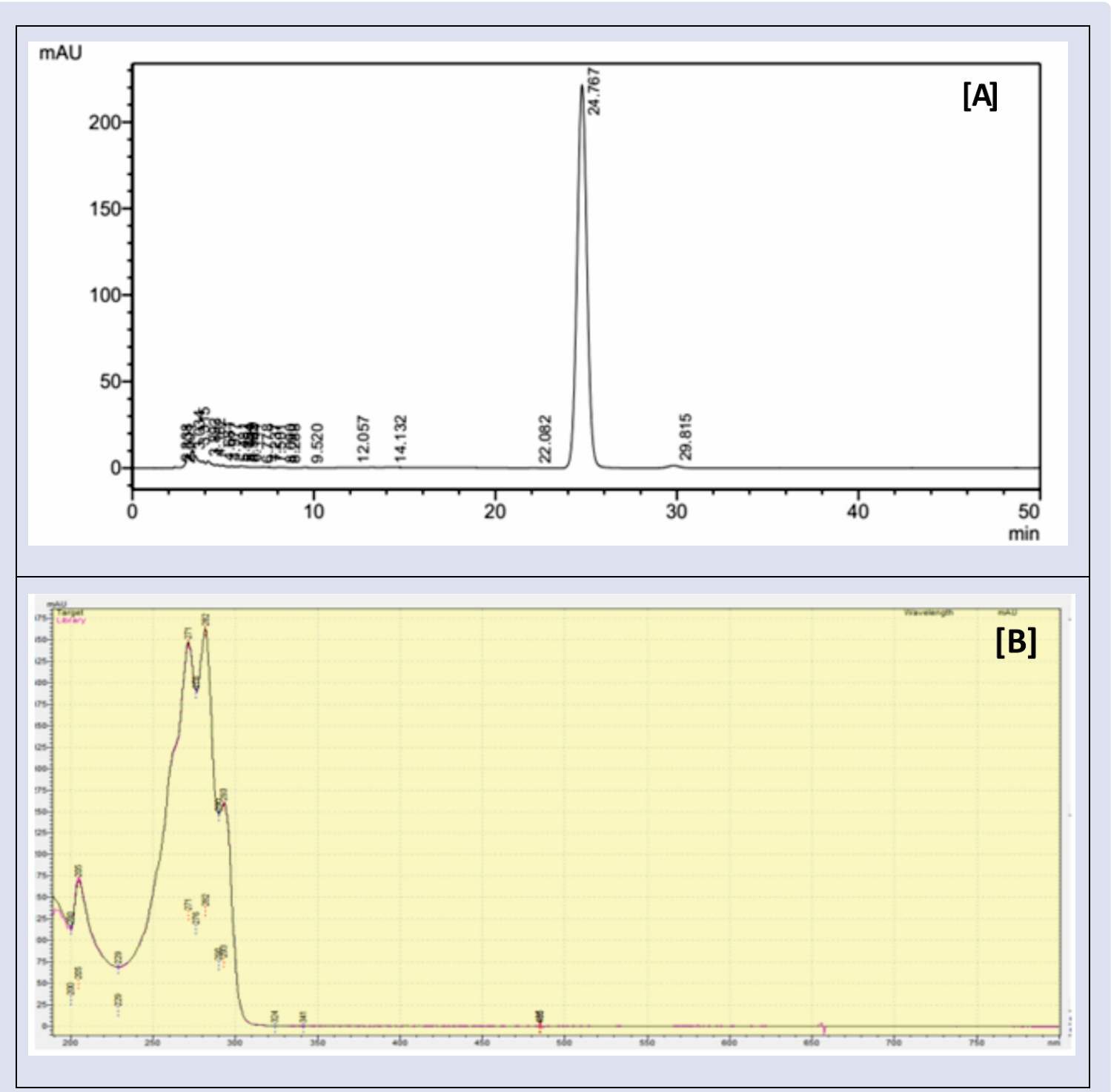

Figure 1: [A] HPLC Chromatogram of A.blazei isolate profile from hexane extract using a $4.6 \times 250 \mathrm{~mm}$ RP shimpack column, carried out with methanol solvent: acid water (99.5: 0.5 ), injection volume $0.04 \mathrm{~mL}$, flow rate $0.7 \mathrm{~mL} / \mathrm{minute}$. [B] UV-Vis Spectra of isolate A.blazei from n-hexane extract by 1900i UV-Vis Spectrophotometer.

$\mathrm{J}=6.6 \mathrm{~Hz}, \mathrm{H}-27$ ) bpj, (iii) there is a characteristic signal in the chemical shift of $3.62 \mathrm{bpj}$ which appears as a multiplet which is characteristic of the presence of $-\mathrm{OH}$ bound to $\mathrm{C}-3^{6}$, and (iv) there is a typical signal in the chemical shift of 5.38-5.57 bpj which appears as a multiplet indicating the presence of a double bond, as showed Table 1. The spectrum profile is in accordance with the literature search of ergosterol. Based on the ${ }^{13} \mathrm{CNMR}$ spectrum: (i) there are 28 carbon signals, (ii) one oxygenated carbon signal at $70.5 \mathrm{bpj}$ which correlates with the typical multiplet signal at $3.62 \mathrm{bpj}$ chemical shift ( $\left.{ }^{1} \mathrm{HNMR}\right)$ which also shows the presence of - $\mathrm{OH}$ bound to carbon which is oxygenated, and (iii) there is a chemical shift at $116.4-141.5 \mathrm{ppm}$ which indicates the presence of a double bond at positions C-6, C-7, C-21 and C-22 ${ }^{20}$. From the ${ }^{1} \mathrm{HNMR}$ and ${ }^{13} \mathrm{CNMR}$ data, it is known that the compound is an ergosterol structure with 28 carbon atoms, 44 proton atoms, and 1 atom oxygen, which is in accordance with the mass spectrophotometer data showing the results of $\mathrm{m} / \mathrm{z} 397.23\left[\mathrm{M}^{+}-\mathrm{H}\right]$ which is consistent with the molecular formula $\mathrm{C}_{28} \mathrm{H}_{44} \mathrm{O}$ (Figure 2).

Ergosterol [ $(3 \beta)$-Ergosta-5,7,22-trien-3-ol] m/z 397.23 is identical. Based on the library's 1H-NMR spectrum, there are six methyl signals at $\delta 0.94(3 \mathrm{H}, \mathrm{s}, \mathrm{H}-18)$ shift; $0.63(3 \mathrm{H}, \mathrm{s}, \mathrm{H}-19) ; 1.03(3 \mathrm{H}, \mathrm{d}, \mathrm{J}=6.6$ $\mathrm{Hz}, \mathrm{H}-21) ; 0.91(3 \mathrm{H}, \mathrm{d}, \mathrm{J}=6.6 \mathrm{~Hz}, \mathrm{H}-28) ; 0.83(3 \mathrm{H}, \mathrm{d}, \mathrm{J}=6.7 \mathrm{~Hz}$, $\mathrm{H}-26) ; 0.82(3 \mathrm{H}, \mathrm{d}, \mathrm{J}=6.7 \mathrm{~Hz}, \mathrm{H}-27) \mathrm{bpj}$, there is a characteristic signal in the chemical shift of $3.63 \mathrm{bpj}$ which appears as a multiplet, which is characteristic of the presence of $-\mathrm{OH}$ bound to $\mathrm{C}-3$. Based on the ${ }^{13} \mathrm{CNMR}$ spectrum, there are 28 carbon signals, one oxygenated carbon signal at $70.4 \mathrm{bpj}$ which is correlated with the multiplet typical signal at $3.63 \mathrm{bpj}$ chemical shift $\left({ }^{1} \mathrm{HNMR}\right)$ which also shows the presence of -OH bound to oxygenated carbon, there is chemical shift at $116.4-139.7$ bpj which indicates the presence of a double bond at positions C- 6 , C-7, C-21 and C-22..$^{2,515}$ Comparison of Ergosterol Proton and Carbon Shifting Data ${ }^{1} \mathrm{HNMR}$ and ${ }^{13} \mathrm{CNMR}$ Spectrums (Table 1).

\section{Anticancer activity of extracts, fractions, subfractions, and isolates (Ergosterol)}

The activity was determined based on the MTT method that was guide by Bioactivity Guided Isolation of ergosterol isolate on MCF-7 cells having an $\mathrm{IC}_{50}$ value of $43.10 \mu \mathrm{g} / \mathrm{mL}$. This value indicates that the compound has strong cytotoxicity anticancer activity. ${ }^{25}$ 
Table 1: Data on Proton and Carbon Shifting of compound 1 in the ${ }^{1}$ HNMR and ${ }^{13}$ C-NMR Spectrums.

\begin{tabular}{|c|c|c|c|c|c|c|}
\hline C & Compound-1 ${ }^{1}$ HNMR & $\begin{array}{c}\text { Library-1 (Alexandre dkk, } \\
\text { 2017) } \\
\end{array}$ & Library-2 (Li, X., 2015) & Compound- $1{ }^{13}$ CNMR & $\begin{array}{c}\text { Library-1 (Alexandre } \\
\text { dkk, 2017) }\end{array}$ & $\begin{array}{c}\text { Library-2 (Li, X., } \\
\text { 2015) }\end{array}$ \\
\hline 1 & - & - & - & 38.4 & 38.4 & 38.5 \\
\hline 2 & - & - & - & 32.1 & 31.9 & 32.1 \\
\hline 3 & $3.62 \mathrm{~m}(1 \mathrm{H})$ & $3.64 \mathrm{~m}(1 \mathrm{H})$ & $3.61 \mathrm{~m}(1 \mathrm{H})$ & 70.5 & 70.5 & 70.5 \\
\hline 4 & & - & - & 40.9 & 40.8 & 40.9 \\
\hline 5 & - & - & - & 139.8 & 139.8 & 139.8 \\
\hline 6 & $5.57 \mathrm{dd}(1 \mathrm{H})$ & $5.58 \mathrm{dd}(5.5 ; 3.0 \mathrm{~Hz}, 1 \mathrm{H})$ & $5.56 \mathrm{dd}(5.4,2.2 \mathrm{~Hz}, 1 \mathrm{H})$ & 119.7 & 119.6 & 119.7 \\
\hline 7 & $5.38 \mathrm{~m}(1 \mathrm{H})$ & 5,38dd $(5.4,2.9 \mathrm{~Hz}, 1 \mathrm{H})$ & $5.38 \mathrm{dd}(5.4,2.5 \mathrm{~Hz}, 1 \mathrm{H})$ & 116.4 & 116.3 & 116.4 \\
\hline 8 & - & - & - & 141.5 & 141.4 & 141.3 \\
\hline 9 & & - & - & 46.3 & 46.2 & 42.3 \\
\hline 10 & - & - & - & 37.1 & 37.1 & 37.1 \\
\hline 11 & - & - & - & 21.2 & 21.1 & 21.1 \\
\hline 12 & - & -- & -- & 39.2 & 39.1 & 39.1 \\
\hline 13 & -- & -- & -- & 42.9 & 42.9 & 42.9 \\
\hline 14 & - & - & - & 54.6 & 54.6 & 54.6 \\
\hline 15 & - & - & - & 23.0 & 22.9 & 23.1 \\
\hline 16 & - & - & - & 28.4 & 28.3 & 28.3 \\
\hline 17 & - & - & - & 55.8 & 55.7 & 55.8 \\
\hline 18 & $0.93 \mathrm{~s}(3 \mathrm{H})$ & $0.95 \mathrm{~s}(3 \mathrm{H})$ & $0.95 \mathrm{~s}(3 \mathrm{H})$ & 12.1 & 12.1 & 12.1 \\
\hline 19 & $0.62 \mathrm{~s}(3 \mathrm{H})$ & $0.65 \mathrm{~s}(3 \mathrm{H})$ & $0.63 \mathrm{~s}(3 \mathrm{H})$ & 16.4 & 16.3 & 16.3 \\
\hline 20 & - & & & 40.3 & 40.3 & 40.4 \\
\hline 21 & $1.03 \mathrm{~d}(\mathrm{~J}=6,5,3 \mathrm{H})$ & $1.04 \mathrm{~d}(\mathrm{~J}=6.6 \mathrm{~Hz}, 3 \mathrm{H})$ & $1.00 \mathrm{~d}(\mathrm{~J}=6.6 \mathrm{~Hz}, 3 \mathrm{H})$ & 21.2 & 21.1 & 21.2 \\
\hline 22 & $5.19 \mathrm{~m}(1 \mathrm{H})$ & $5.20 \mathrm{~m}(1 \mathrm{H})$ & $5,20 \mathrm{~m}(1 \mathrm{H})$ & 135.7 & 135.6 & 135.6 \\
\hline 23 & $5.21 \mathrm{~m}(1 \mathrm{H})$ & $5,21 \mathrm{~m}(1 \mathrm{H})$ & $5.20 \mathrm{~m}(1 \mathrm{H})$ & 132.0 & 131.9 & 132.1 \\
\hline 24 & - & & & 42.9 & 42.9 & 42.9 \\
\hline 25 & - & & & 33.1 & 33.1 & 33.1 \\
\hline 26 & $0.84 \mathrm{~d}(\mathrm{~J}=6,6 \mathrm{~Hz}, 3 \mathrm{H})$ & $0.84 \mathrm{~d}(\mathrm{~J}=6,7 \mathrm{~Hz}, 3 \mathrm{H})$ & $0.84 \mathrm{~d}(\mathrm{~J}=6,7 \mathrm{~Hz}, 3 \mathrm{H})$ & 20.0 & 19.9 & 20 \\
\hline 27 & $0.82 \mathrm{~d}(\mathrm{~J}=6,6 \mathrm{~Hz}, 3 \mathrm{H})$ & $0.82 \mathrm{~d}(\mathrm{~J}=6,7 \mathrm{~Hz}, 3 \mathrm{H})$ & $0.83 \mathrm{~d}(\mathrm{~J}=6,7 \mathrm{~Hz}, 3 \mathrm{H})$ & 19.7 & 19.7 & 19.7 \\
\hline 28 & $0.92 \mathrm{~d}(\mathrm{~J}=6,5 \mathrm{~Hz}, 3 \mathrm{H})$ & $0.92 \mathrm{~d}(\mathrm{~J}=6,6 \mathrm{~Hz}, 3 \mathrm{H})$ & $0.95 \mathrm{~d}(3 \mathrm{H})$ & 17.7 & 17.6 & 17.6 \\
\hline
\end{tabular}

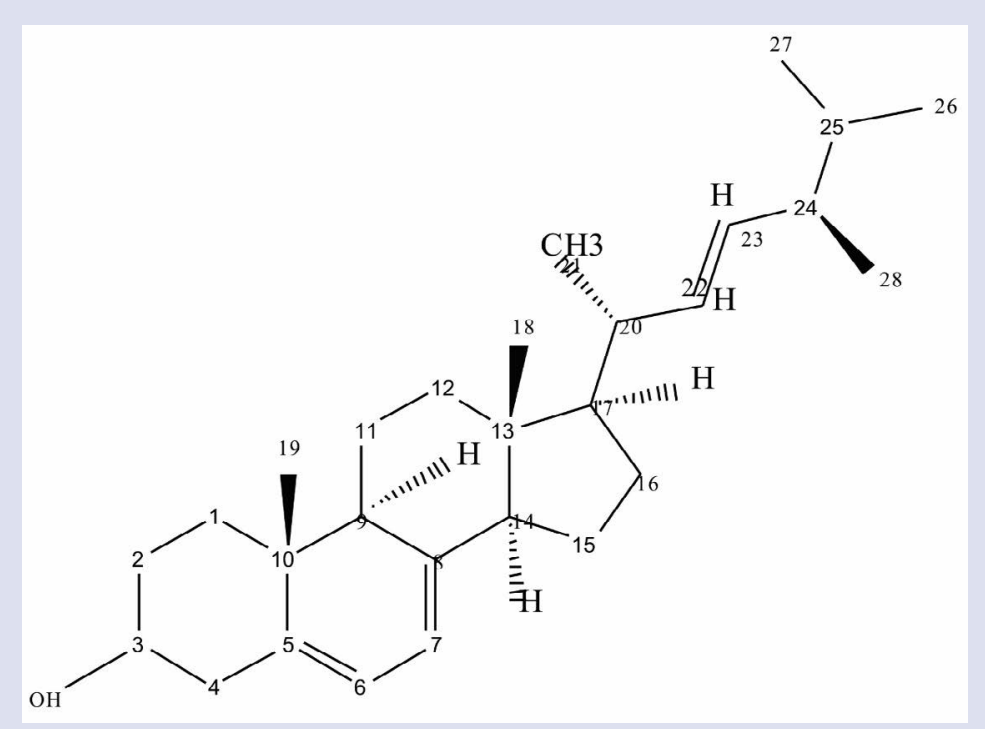

Figure 2: Ergosterol structure. 
Results of MCF-7 cell cycle regulation due to ergosterol treatment

The treatment of ergosterol compounds at a dose of $\mathrm{IC}_{50} 43.1 \mu \mathrm{g} / \mathrm{mL}$ on MCF-7 cell proliferation caused changes in the cell cycle with an increase in G2 phase accumulation $27.3 \%$. Based on the results of statistical tests showed that the increase in G2-M phase accumulation was significantly different from control $(p<0.001)$. changes in the distribution of the cell cycle after treatment will direct the resting cells to a certain phase in the cell cycle, so that this causes the induction of cell death. These results lead to the induction of cell death. The results of the MCF-7 cell cycle analysis due to treatment of the ergosterol are presented in Figure 3.

The result of the mechanism of action of Ergosterol on the induction of apoptosis

The results of the analysis of cell apoptosis caused by ergosterol treatment (isolates) on MCF-7 cells showed that the cells experienced an increase in early apoptosis $30.4 \%$, late apoptosis $16.4 \%$, and a decrease in necrosis $7.4 \%$. Based on the results of statistical tests showed that the increase in apoptosis induction was significantly different from the control $(p<0.001)$. The increase in cell apoptosis also correlates with the increase in cell accumulation in the G2/M phase. The results of the apoptosis induction analysis of MCF-7 cells due to treatment of ergosterol compounds a showed in Figure 4.

\section{DISCUSSION}

This research has identified active anticancer compounds from n-hexane extract of Agaricus blazei Murill. The terpenoid compound in the form of ergosterol has identified, based on the results of HRMS analysis revealed the ion peak $\left(\mathrm{M}^{+}-\mathrm{H}\right)$ at 397, 23 and MS analysis is consistent with the molecular formula $\mathrm{C}_{28} \mathrm{H}_{44} \mathrm{O}{ }^{2,15}$ Agaricus blazei Murill has been widely reported to have anticancer activity of several cancer cells, including leukemia cells ${ }^{1}$, prostate cells ${ }^{27}$, human lung LU99 and stomach KATO III cancer line ${ }^{26}$, pancreatic cells ${ }^{16}$, while for MCF-7 cells it has not been reported. Ergosterol isolated from Pleurotus salmoneostramineus on Trypanosoma cruzi activity ${ }^{2}$, isolation in Amauroderma rude to the activity of murine cancer cell line B16
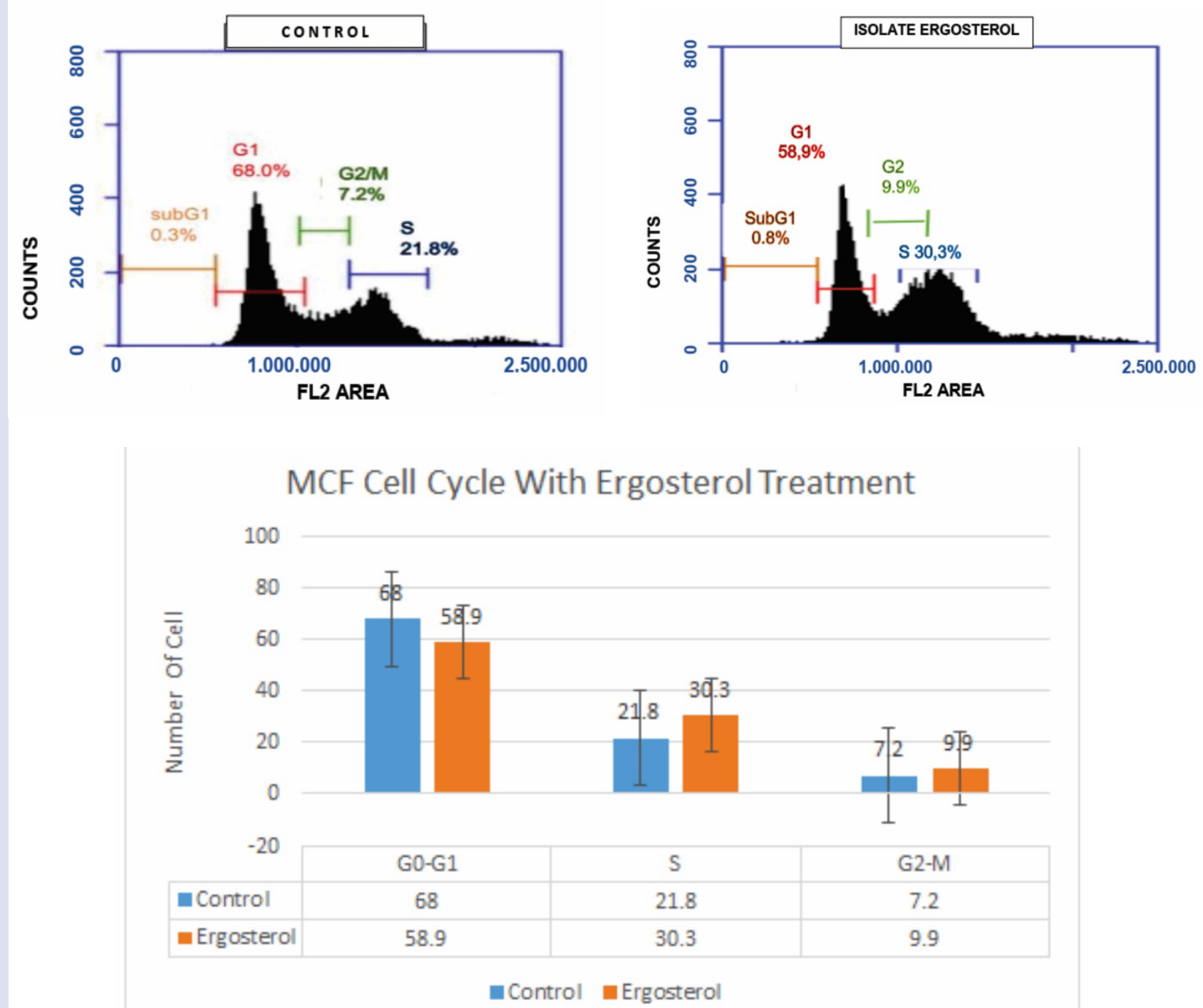

Figure 3: Profile of the distribution of each phase (G1/M and G2/M) in the cell cycle analyzed by fluocytometry with propidium iodide (PI) staining. Cell accumulation in G2/M indicates induction of cell death. 

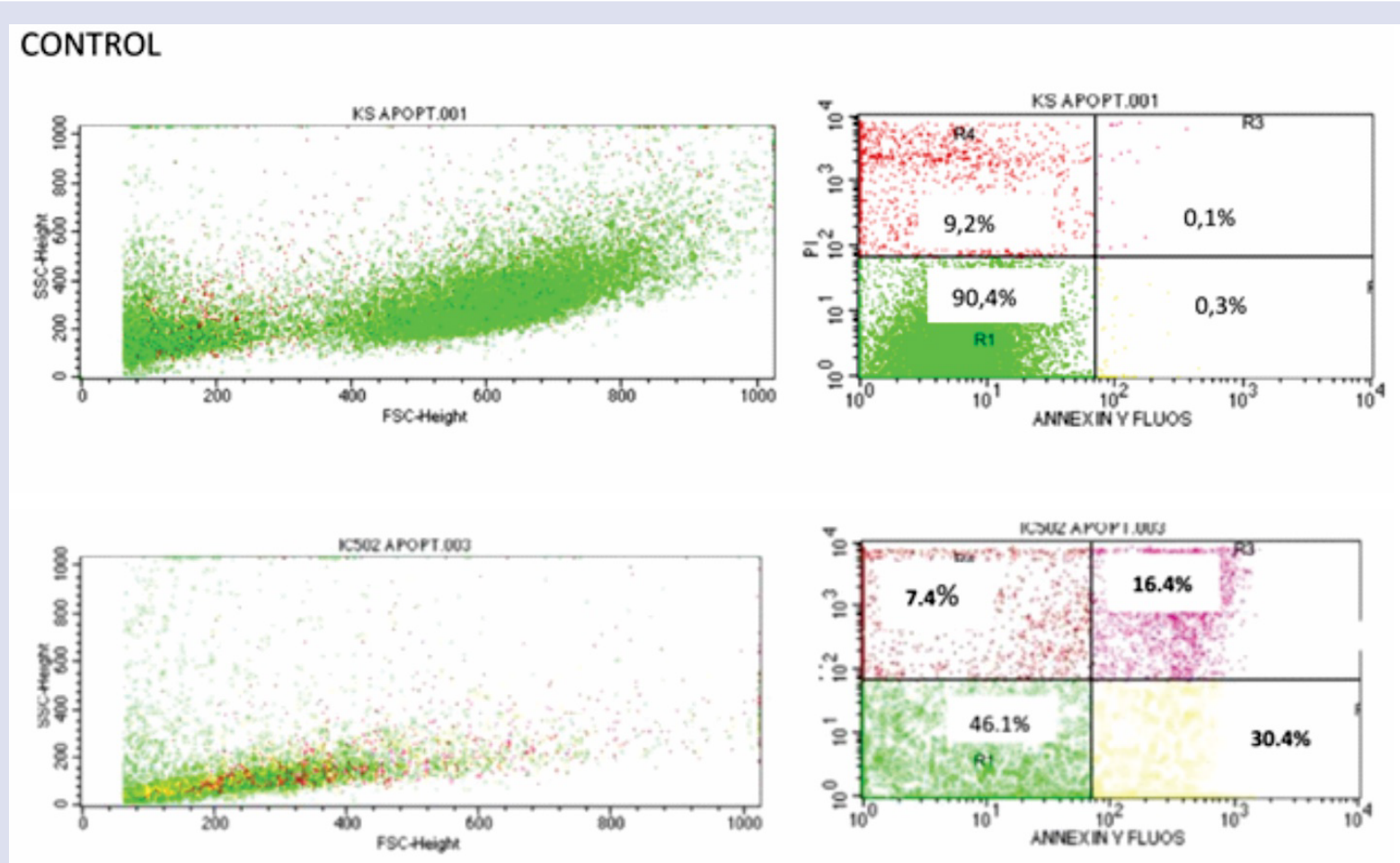

\section{APOPTOSIS INDUCTION}

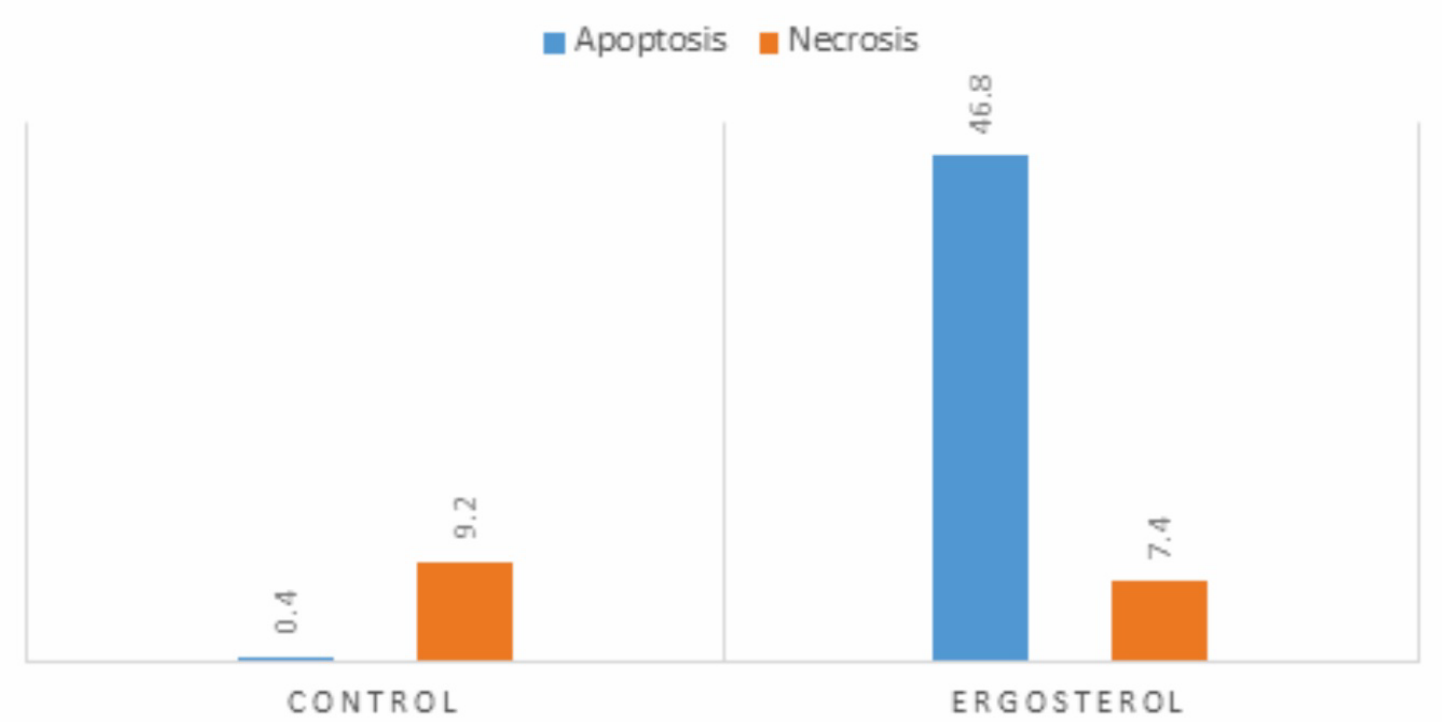

Figure 4: Results of cell distribution and induction analysis of cell death using the fluocytometry method due to treatment of Compound 1 (A) MCF-7 cell control, (B) treatment of ergosterol compounds on MCF-7 cells. (R1 = living cells, R2 = early apoptosis, R3 = late apoptosis, R4 = necrosis).

and breast cancer cells MDA-MB-231 $1^{15}$. Isolation of Gonaderma sp on dipeptidyl peptidase- 4 inhibitory activity ${ }^{7}$, can also inhibit human tumor cells and HUVECc in vitro 9 . Ergosterol from the isolation of Agaricus blazei Murill, which has activity against cells of MCF-7 cancer, have not reported. The results of the isolation of Agaricus blazei Murill, namely ergosterol, including having strong cytotoxicity activity with an $\mathrm{IC}_{50}$ value of $43.10 \mu \mathrm{g} / \mathrm{mL}$. In this mechanism, cancer cells will die naturally (programmed), so as not to cause a systemic inflammatory response that causes serious side effects even to death. Ergosterol is a terpenoid compound, a white powder, in terms of cell regulation, it shows that ergosterol treatment on MCF-7 cells causes cell cycle inhibition in the G2/ M phase, which is characterized by an increase in the number of cells in the G2 / M phase by $9.9 \%$. This increase in the $\mathrm{G} 2 / \mathrm{M}$ phase has an effect on the induction of apoptosis of cancer cells.

Ergosterol isolated from Amaouroderma rude can suppress the growth of MDA-MB-231 breast cancer cells through the apoptotic pathway by increasing FOXO3 expression ${ }^{15}$. FOXOs can induce apoptosis via the mitochondrial pathway as well as via the Fas ligand (FasL). Myochondrial pathways through the proapoptotic Bcl-2 family, such 
as Bim and bNIP3, cause mitochondrial permiability, which activates caspase9, caspase 3 and apoptosis. The Fas ligand pathway is to activate FasL and TRAIL which will activate caspase 8, caspase 3 and finally increase the induction of apoptosis

\section{CONCLUSION}

Ergosterol isolated from n-hexane extract of Agaricus blazei Murill is a good candidate for the development of anti-cancer drugs, which are able to increase the apoptosis induction of MCF-7 cancer cells through cell cycle inhibition mechanisms in the G2 / M phase.

\section{ACKNOWLEDGMENTS}

PT ASIMAS as the raw material provider for Agaricus blazei Murill.

\section{REFERENCES}

1. Akiyamaa,H, Endob M, Matsuib T, Katsudaa I, Emid N, Kawamotoe $Y$, et al. Agaritine from Agaricusblazei Murill induces apoptosis in the leukimia cell line U937. Biochimica et BiophisicaActa (BBA). $2011 ; 1810(5): 519-25$

2. Alexandre TR, Lima ML, Galuppo MK, Mesquita JT, do Nascimento MA, Dos Santos AL, et al. Ergosterol isolated from the basidiomycete Pleurotus salmoneostramineus affects Trypanosoma cruzi plasma membrane and mitochondria. J Venom Anim Toxins Incl Trop Dis. 2017;23:30.

3. American cancer society. Breast cancer: key statistic of breast cancer. 2020 January. Availableat: http:/ /www.cancer. org/ cancer/ breastcancer/ detailedguide/ breast-cancer-key-statistics

4. Din Y, Bao HY, Bau T, Li Y, Kim YH. Antitumor components from Naematoloma fasciculare. J Microbiol Biotechnol. 2009;19:1135-8.

5. Budiprama K. Characterization of Several Gonaderma sp. in Indonesia and inhibition activity of dipeptide peptidase-4 and alpha glycosidase, the main metabolites of Ganoderma austral (Fr). Dissertation, Institute of Technology of Bandung. Doctoral Study Program, 2020.

6. Breitmaier, E and Bauer G. C-NMR-Spektroskopie. Thieme, Stuttgart; 1997.

7. Bruggemann R, Orlandi JM, Benati, FJ. Antiviral Activity Of Agaricus blazeii Murill ss. Heinem Extract Against Human And Bovine Herpesviruses In Cell Culture. Brazilian Journal of Microbiology. 2006.37(4).

8. Cancer Chemoprevention Research Center. MTT Method Cytotoxic Test Protocol. Yogyakarta: Faculty of Pharmacy, Gadjah Mada University, 2013.

9. Shaodan C, Tianqiao Y, Yifang Z, Jiyan S, Chunwei J, Yizhen X. AntiTumor and Anti-Angiogenic Ergosterols from Ganoderma lucidum. Front Chem. 2017;5:85.

10. Department of Health Republic of Indonesian. World Cancer Day 2019. Accessed from https://www.kemkes.go.id/pdf.php?id=19020100003 [cited 2020 November 23].

11. Firenzuoli F, Gori L, Lombardo G. The Medicinal Mushroom Agaricus blazei Murrill: Review of Literature and Pharmaco-Toxicological Problems. eCAM 2008;5(1):3-15.

12. Jiahua J and Sliva D. Novel Medicinal Mushroom Blend Suppresses Growth and Invasiveness of Human Breast Cancer cells. International Journal of Oncology. 2010;37(6):1529-36.
13. Kerrigan RW, Callac $P$, Parra LA. New and rare taxa in Agaricus section Bivelares (Duploannulati), Mycologia. 2008;6:876-92.

14. Kobayashi H, Yoshida R, Kanada Y, Terao T, et al. Supressing Effects of Daily Oral Supplementation of $\beta$-Glucan extracted from Agaricus blazei Murill on Spontaneous and Peritoneal Disseminated Metastatis in Mouse Model. Journal of Cancer Research and Clinical Oncology. 2005;131(8):527-38.

15. Xiangmin L Qingping W, Yizhen X, Yinrun D, William DW, Mouna S, et al. Ergosterol purified From Medical Mushroom Amauroderma rude Inhibits Cancer Growth In Vitro and In Vivo By Up-Reulating Multiple Tumor Suppressors. Oncotarget. 2015:6(19).

16. Matsushita Y, Furutani Y, Matsuoka R, Furukawa T. Hot water Extract of Agaricus blazei Murill specifically inhibits And Induces Apoptosis in Human Pancreatic Cancer Cells. BMC Complementary and Alternative Medicine. 2018;18(1).

17. Misgiati. The anticancer ability of the extract of Dewa's mushroom (Agaricus blazei Murill) on cervical cancer cells as reading material for traditional medicine. Thesis. Malang State of University, 2011.

18. Misgiati M, Sukardiman S, Widyawaruyanti. Anti-Breast Cancer Potency of Multistage Extraction from Jamur Dewa (Agaricus blazei Murill) Solvents on MCF-7 Cells. Indonesian Journal Of cancer Chemoprevention. 2017;8(2).

19. Novaes MRCB, Novaes LCG, Taveira VC. Natural Product From Agaricales Medicinal Mushrooms: Biology, Nutritional Properties, and Pharmacological Effects on Cancer. Revista Brasileira de Cancerologia. 2007;53(4):411-20.

20. Pavia DL, Lampman GM, Kriz GS, Vyvyan JR. Introduction to Spectroscopy $4^{\text {th }}$ edition. Brook/Cole, Cengage Learning, 2001.

21. Pubchem. National Library of Medicine. Ergosterol. https:// pubchem. ncbi. nlm. nih. gov/ compound/ ergosterol. [Accessed: 25 November 2020].

22. Queiroz,EAIF, Fortes ZB, Cunha MAA, Barbosa AM, Khaper N, Dekker $\mathrm{RFH}$. Antipoliferative and Pro-Apoptotic Effects of Three Fungal Exocellular $\beta$-Glucan in MCF-7 Breast cancer Cells Is Mediated By Oxidative Stress, AMP-Activated Protein Kinase (AMPK) And The Forkhead Transcription Factoe, FOXO3a. The International Journal of Biochemistry and Cell Biology. 2015;67:14-24.

23. Silva DDD, Rapior, S, Fons F, Bahkali AH, Hyde KD. Medical Mushroom in Supportive Cancer Therapies An Approach To Anti-Cancer Effects And Putative Mechanism Of Action. Fungal Diversity. 2012;55:1-35.

24. Tangen JM, Holien T, Mirlashari MR, Misund K, Hetland G. Cytotoxic Effect on Human Myeloma Cell and Leukemic Cells by The Agaricus blazei Murill Based Mushroom Extract, Andosan. Biomed Res Int. 2017;2017:2059825.

25. Weerapreeyakul N, Nonpunya A, Barustux S, Thitimetharoch T, Sripanidkulchai B. Evaluation of the anticancer potential of six herbs against a hepatoma cell line. Chinese Medical Journal. 2012;7(15):1-7.

26. Wu B, Cui J, Zhang C, Li Z. A Polysaccharide from Agaricusblazei Inhibits Proliferation and Promote Apoptosis of Osteosarcona Cells. International Journal of Biological Macromolecules. 2012;5(4):111620.

27. Yu CH, Kana SF, Shub CH. Inhibitory mechanisms of Agaricus blazei Murill on the growth of prostate cancer In Vitro and In Vivo. Journal of Nutritional Biochemestry. 2009;20:753-64. 


\section{GRAPHICAL ABSTRACT}
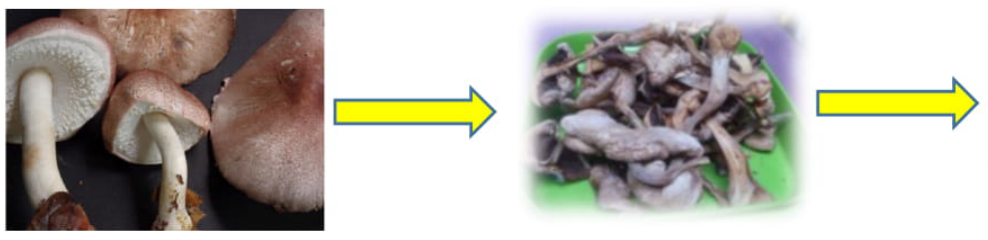

EXTRACTION

\section{(Maseration n-Hexan)}

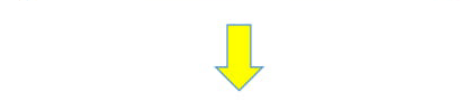

FRACTINATION

(N-Hexan: Aethyi Acetate)

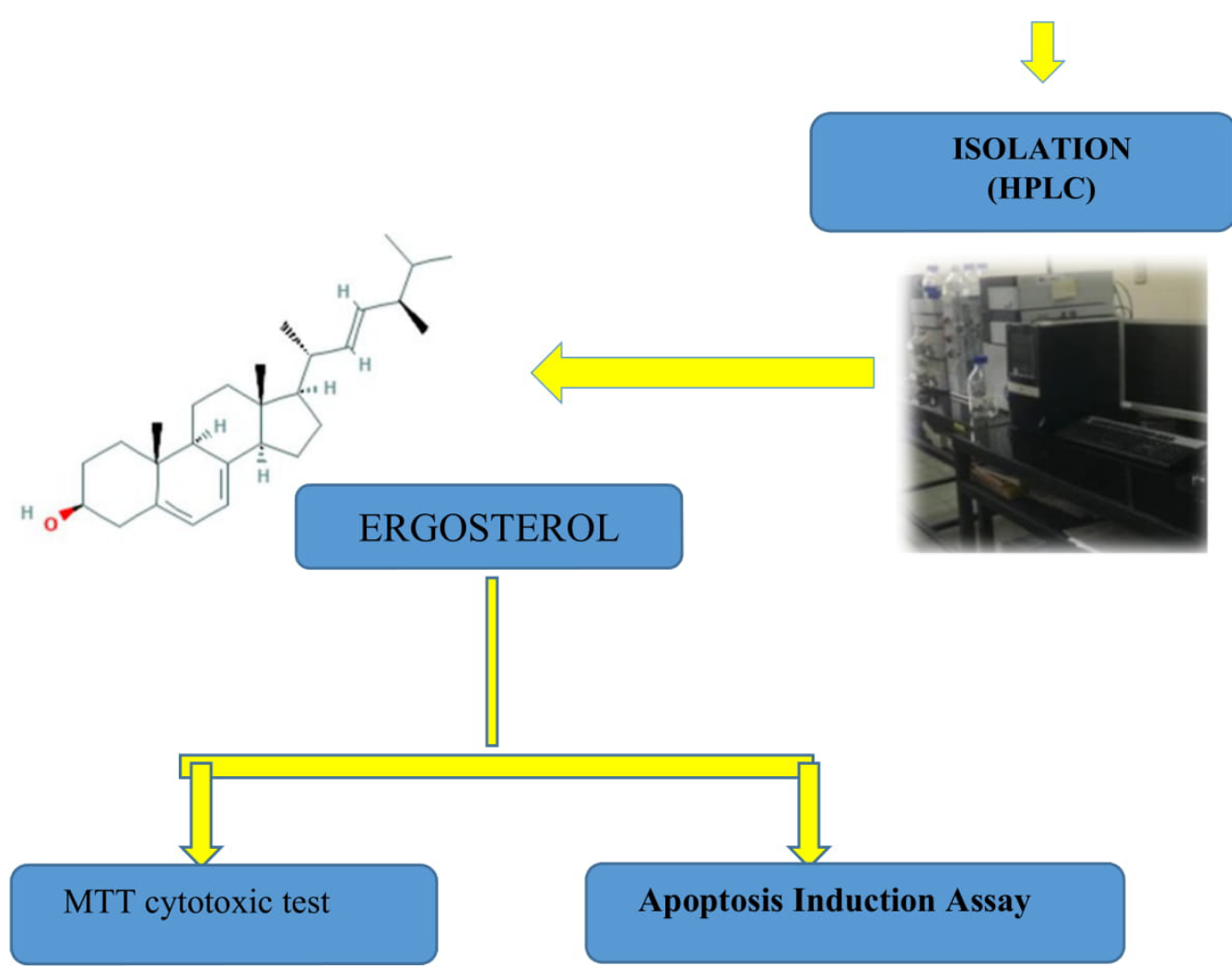

\section{ABOUT AUTHORS}

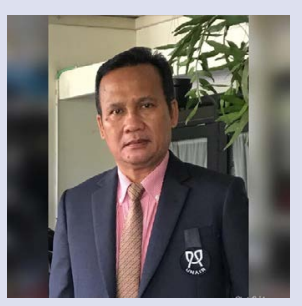

Sukardiman is Professor Pharmacognosy on Department of Pharmacognosy and Phytochemistry, Faculty of Pharmacy, Universitas Airlangga, Surabaya, Indonesia. He has vast experience in the area of pharmacognosy, natural product and pharmacology. He has projects in developing product antidiabetic, anticancer from Indonesian herbal medicine, and herbal standardization. Guiding students for PhD andstudies of various Universities. He has publication in National and International Journal.

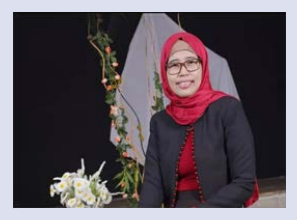

Misgiati is is a doctoral student at Faculty of Pharmacy, University of Airlangga and also a lecturer at Academic of Pharmacy and Food Analyst of Putra Indonesia Malang. Her research is focuses on drug discovery for anticancer drugs from bioactive natural products. 


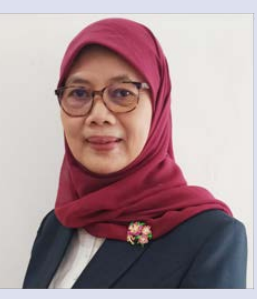

Aty Widyawaruyanti is a lecturer, head of Master Program of Pharmaceutical Sciences, Faculty of Pharmacy, Universitas Airlangga and researcher at Natural Product Medicine Research and Development (NPMRD), Institute of Tropical Disease, Universitas Airlangga. She obtained her bachelor degree in Pharmacy at Faculty of Pharmacy, Padjajaran University. She was further persued her Master and Doctoral degree at Faculty of Pharmacy, Universitas Airlangga. Her research is focuses on drug discovery from bioactive natural products especially drug discovery for antimalarial drugs.

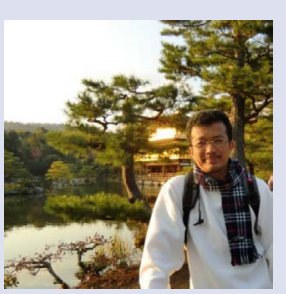

Sentot Joko Raharjo as Lecturer in Acadenic of Pharmacy and Food Analyst of Putra Indonesia Malang Indonesia. He has vast experience in the area of Pharmacy Analyst, Medical Chemistry, Natural Organic Chemistry, and Food Function. He has projects gen database, protein database and active compound database in UB Smonagen Group. He has publication in National and International Journal. He research is focuses in silico on drug discovery from bioactive natural product compounds for various diseases therapy.

Cite this article: Misgiati M, Widyawaruyanti A, Raharjo SJ, Sukardiman S. Ergosterol Isolated from Agaricus blazei Murill N-Hexane Extracts as Potential Anticancer MCF-7 Activity. Pharmacog J. 2021;13(2): 418-26. 